\title{
Porphyrin metabolism and haem biosynthesis in Gilbert's syndrome
}

\author{
K E L McCOLL, G G THOMPSON, E EL OMAR, M R MOORE, \\ AND A GOLDBERG \\ From the University Dept. Medicine, Gardiner Institute, Western Infirmary, Glasgow
}

SUMMARY Studies in 14 patients with unconjugated hyperbilirubinaemia caused by Gilbert's syndrome have revealed abnormalities of the enzymes of haem biosynthesis measured in peripheral blood cells. The activity of the penultimate enzyme of haem biosynthesis protoporphyrinogen (PROTO) oxidase was reduced at $3.1 \pm 2.6 \mathrm{nmol} \mathrm{PROTO} / \mathrm{g}$ protein $/ \mathrm{h}$ (mean \pm ISD) compared with $8 \cdot 2 \pm 5 \cdot 1$ in controls $(\mathrm{p}<0.005)$. This was associated with a compensatory increase in the activity of the initial and rate controlling enzyme of the pathway delta-aminolaevulinic acid (ALA) synthase at $866 \pm 636 \mathrm{nmol} \mathrm{ALA} / \mathrm{g} / \mathrm{protein} / \mathrm{h}$ compared with $156 \pm 63$ in controls $(\mathrm{p}<0 \cdot 001)$. Unlike variegate porphyria in which there is a genetic deficiency of PROTO oxidase there was no increased excretion of porphyrins or their precursors in Gilbert's syndrome. Accentuation and subsequent correction of the unconjugated hyperbilirubinaemia with rifampicin produced reciprocal changes in PROTO oxidase activity indicating that bilirubin may be inhibiting the activity of this enzyme.

Gilbert's syndrome originally described in 1901 by Gilbert and Lereboullet ${ }^{1}$ is a benign disorder affecting $2-5 \%$ of the population. It is characterised by mild, chronic, variable unconjugated hyperbilirubinaemia in the presence of otherwise normal standard liver function tests and normal liver histology. The hyperbilirubinaemia is mainly the result of reduced bilirubin clearance ${ }^{2}$ though in approximately $50 \%$ of subjects with the syndrome, there is also an increased rate of bilirubin formation because of slightly shortened red blood cell survival. ${ }^{3}$ The cause of the impaired bilirubin clearance remains unclear. Compartmental analysis of radiobilirubin kinetic studies suggests a reduction in both the uptake and conjugation of bilirubin,,$^{24}$ though non-compartmental analytical techniques have failed to confirm the presence of an uptake defect. ${ }^{5}$ In vitro assays of bilirubin conjugation have consistently shown reduced bilirubin-UDP-glucuronyl trans-

Address for correspondence: Dr Kenneth E L McColl, University Dept. Medicine, Gardiner Institute, Western Infirmary, Glasgow G11 6NT.

Received for publication 26 June 1986. ferase activity. ${ }^{6-8}$ Gilbert's syndrome may be a heterogenous disorder. ${ }^{9}$ We wish to report a previously unrecognised biochemical abnormality in patients with the syndrome which involves the enzymes of haem biosynthesis and discuss its relationship to the previously reported disturbances in haem degradation.

\section{Methods}

PATIENTS

Eleven male and three female patients previously diagnosed to have Gilbert's syndrome were studied. Their mean age was 33 years (range 19-59). Total bilirubin concentrations at the time studied ranged from $19-54 \mu \mathrm{mol} / 1$ (normal range 5-17) with a mean value of $31 \mu \mathrm{mol} / \mathrm{l}$. In each case the bilirubin was predominantly unconjugated and the reticulocyte count less than $2 \%$. None of the patients was on any medication. For comparison, 20 normal subjects (15 men and five women, mean age 32 years) and nine patients with variegate porphyria (eight women and one man, mean age 31 years) were also studied. Each of the porphyria patients had experienced an attack 
of porphyria in the past but were all in clinical remission when studied. The diagnosis of variegate porphyria had been confirmed previously by markedly increased faecal porphyrin excretion, consisting predominantly of protoporphyrin, together with increased urinary excretion of ALA and porphobilinogen.

In six of the subjects with Gilbert's syndrome, the effect of rifampicin on the serum bilirubin concentration and activities of leucocyte ALA synthase and PROTO oxidase was studied. It was administered in single daily doses of $600 \mathrm{mg}$ at 2300 hours and blood samples for bilirubin and rifampicin concentrations and enzyme activities obtained nine hours after the second, seventh and 10th doses. In one subject it was not possible to obtain the two later samples.

The activities of the mitochondrial enzymes of the haem pathway ALA synthase, coproporphyrinogen oxidase, PROTO oxidase and ferrochelatase were measured in leucocytes and the cytosolic enzymes, ALA dehydratase, porphobilinogen deaminase and uroporphyrinogen decarboxylase in erythrocytes as previously described..$^{10}$ The PROTO oxidase assay involved the spectrofluorimetric measurement of the rate of protoporphyrin formation using protoporphyrinogen as substrate by a modification of the method of Brenner and Bloomer." In this the reaction was run at $\mathrm{pH} \mathbf{9 . 2}$ and without the addition of sodium EDTA. The serum total bilirubin concentration was determined by the Michaelsson diazo method $^{12}$ and an estimate of the unconjugated fraction obtained from the indirect reaction. Urinary porphyrins were measured by high performance liquid chromatography as described by Seubert and Seubert. ${ }^{13}$ The concentrations of ALA and porphobilinogen in urine, coproporphyrin and protoporphyrin in faeces and protoporphyrin in erythrocytes were measured as described by Moore ${ }^{14}$ Rifampicin concentrations were measured by the method of McConnell et al. ${ }^{15}$

Preliminary studies were carried out to ensure that bilirubin did not interfere with the fluorometric measurement of protoporphyrin and thus affect the measurement of PROTO oxidase activity. In place of the washed leucocytes, bilirubin IX $\alpha$ was dissolved in PROTO oxidase buffer ( $\mathrm{pH}$ 9.2) in varying concentrations up to $300 \mu \mathrm{mol} / 1$, and shown to have no effect on the measurement of protoporphyrin in the final incubation solution. Studies were also performed to ensure that concentrations of rifampicin up to $20 \mu \mathrm{g} / \mathrm{ml}$ did not interfere with the measurement of bilirubin or protoporphyrin.

\section{STATISTICAL ANALYSIS}

Statistical comparison of the values in the three different groups of subjects studied was done using the non-parametric Mann Whitney $U$ test. The Spearman rank correlation was used to assess any relationship between bilirubin concentration and enzyme activities. The study was approved by the Hospital Ethical Committee.

\section{Results}

The activities of the enzymes of haem biosynthesis in the three groups of subjects studied are shown in Table 1. In the subjects with Gilbert's syndrome the mean ALA synthase activity was increased at 866 (range 360-2310) $\mathrm{nmol}$ ALA/g protein/h compared with 156 (range 60-352) in the normal subjects ( $p<0.001)$ (Fig. 1), and the mean PROTO oxidase activity reduced at 3.1 (range $0.3-7 \cdot 8) \pm 2.6 \mathrm{nmol}$ $\mathrm{PROTO} / \mathrm{g}$ protein/h compared with 8.2 (range 3.2-14.9), $(\mathrm{p}<0.005)$ (Fig. 2). These enzyme abnormalities in Gilbert's syndrome were similar to those in variegate porphyria (Figs 1,2 ). In the subjects with Gilbert's syndrome there was no significant correlation between the total bilirubin concentration and the activities of either PROTO oxidase or ALA synthase. All of the 14 subjects with Gilbert's syndrome had normal excretion of porphyrins and precursors whereas each of the subjects with varie-

Table 1 Activities of the enzymes of haem biosynthesis in subjects with Gilbert's syndrome, patients with variegate porphyria and normal controls

\begin{tabular}{|c|c|c|c|c|c|c|c|}
\hline & $\begin{array}{l}\text { ALA synthase } \\
\text { (nmol } A L A / g \\
\text { prot/h) }\end{array}$ & $\begin{array}{l}A L A \\
\text { dehydratase } \\
\text { ( } \mu \text { mol } A L A / \\
1 R B C / \text { min). }\end{array}$ & $\begin{array}{l}\text { PBG deaminase } \\
\text { (nmol UROI } \\
\text { IRBC/h) }\end{array}$ & $\begin{array}{l}\text { Uropor- } \\
\text { phyrinogen } \\
\text { decarboxylase } \\
\text { (nmol COPRO/ } \\
\text { IRBC/h) }\end{array}$ & $\begin{array}{l}\text { Copropor- } \\
\text { phyrinogen } \\
\text { oxidase (nmol } \\
\text { PROTO/g } \\
\text { prot/h) }\end{array}$ & $\begin{array}{l}\text { PROTO oxidase } \\
\text { (nmol PROTO/g } \\
\text { prot/h) }\end{array}$ & $\begin{array}{l}\text { Ferro- } \\
\text { chelatase } \\
\text { (pmol } \\
\text { meschaem/ } \\
\text { gprot/h) }\end{array}$ \\
\hline Normal $(n=20)$ & $156 \pm 63$ & $30 \cdot 8 \pm 87$ & $34 \cdot 7 \pm 6 \cdot 0$ & $50 \pm 25$ & $141 \pm 45$ & $8 \cdot 2 \pm 5 \cdot 1$ & $3 \cdot 8 \pm 2 \cdot 2$ \\
\hline $\begin{array}{l}\text { Gilbert's syndrome } \\
\quad(n=14)\end{array}$ & $866 \pm 636 \dagger$ & $28 \cdot 1 \pm 12 \cdot 8$ & $36 \cdot 8 \pm 4 \cdot 7$ & $36 \pm 24$ & $194 \cdot 5 \pm 72$ & $3 \cdot 1 \pm 2 \cdot 6^{*}$ & $4 \cdot 0 \pm 2 \cdot 2$ \\
\hline $\begin{array}{l}\text { Variegate } \\
\text { porphyria }(n=9)\end{array}$ & $1178 \pm 655 \dagger$ & $25 \cdot 6 \pm 7 \cdot 4$ & $28 \cdot 7 \pm 6 \cdot 2$ & $59 \cdot 6 \pm 39$ & $204 \pm 119$ & $2 \cdot 6 \pm 2 \cdot 4^{*}$ & $2 \cdot 12 \pm 1 \cdot 8$ \\
\hline
\end{tabular}

Results expressed as mean \pm ISD.

${ }^{*} \mathrm{p}<0.005 ; \nmid \mathrm{p}<0.001=$ significance values compared with normal subjects. 


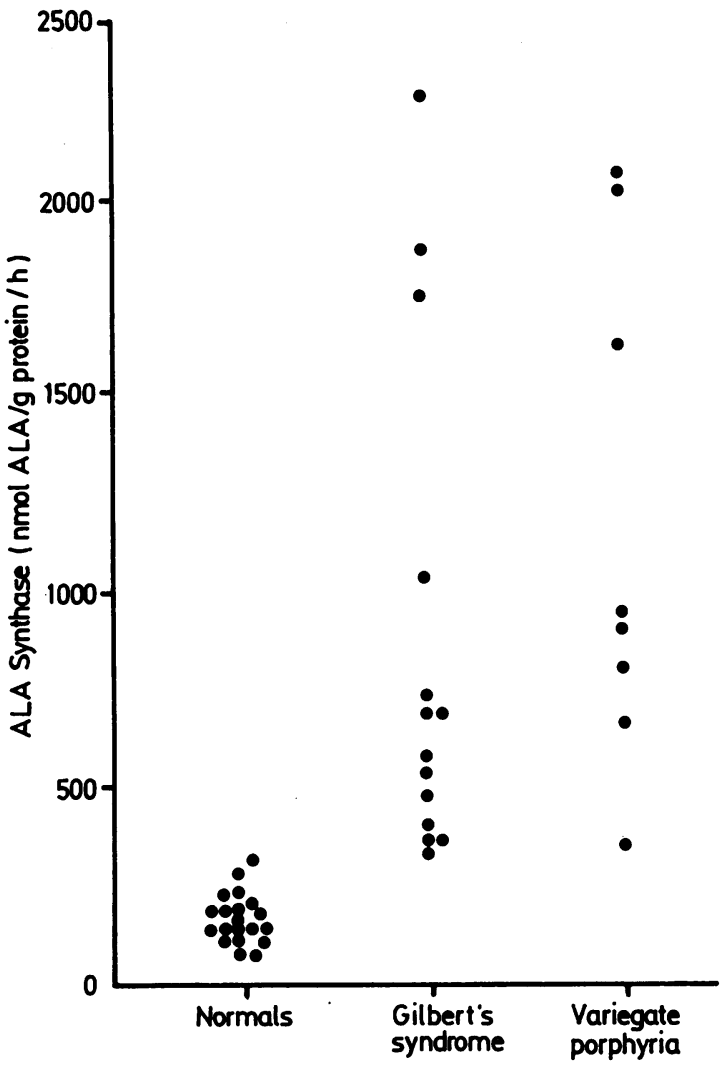

Fig. 1 Activity of ALA synthase in peripheral leucocytes in Gilbert's syndrome, variegate porphyria and normal controls.

gate porphyria had increased faecal excretion of protoporphyrin and coproporphyrin and in five there was also increased excretion of ALA and porphobilinogen in the urine (Table 2). The erythrocyte protoporphyrin concentration was normal in both conditions.

Rifampicin treatment in each of the six patients studied with Gilbert's syndrome initially increased the total bilirubin concentration because of a rise in the unconjugated fraction (Fig. 3). Nine hours after

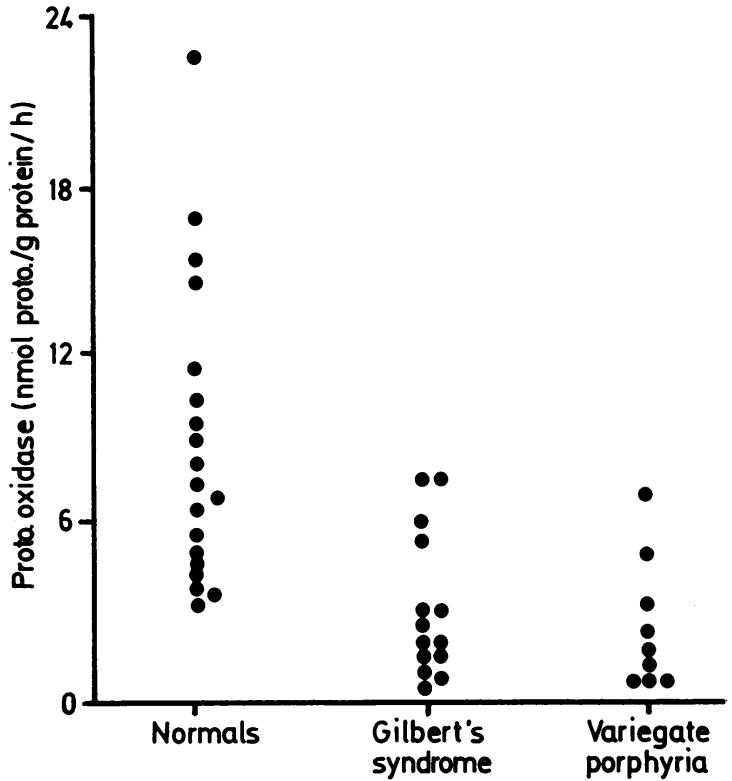

Fig. 2 Activity of PROTO oxidase in peripheral leucocytes in Gilbert's syndrome, variegate porphyria and normal controls.

the second dose the mean total bilirubin concentration was $67 \mu \mathrm{mol} / \mathrm{l}$ (range 35-140) compared with the prerifampicin value of $32 \mu \mathrm{mol} / \mathrm{l}$ (range 19-50). This was associated in each subject with further depression of PROTO oxidase activity and a further increase in ALA synthase activity (Fig. 3). The mean PROTO oxidase activity fell to being $1.7 \mathrm{nmol}$ $\mathrm{PROTO} / \mathrm{g}$ protein/h (range $0 \cdot 3-5 \cdot 2$ ) compared with the pretreatment value of 2.9 (range 1-7.8) and mean ALA synthase activity rose to $897 \mathrm{nmol} \mathrm{ALA} / \mathrm{g}$ protein/h (range 337-1500) compared with the pretreatment value of 535 (range 287-1000). With continued rifampicin therapy the bilirubin concentration fell and by the 10th day of treatment four of the five subjects monitored for this length of time had values within our normal range. Likewise with continued dosing the plasma rifampicin level (mean \pm 1 SD) fell, being $6.54 \pm 3.1 \mu \mathrm{g} / \mathrm{ml}, \quad 1.74 \pm 1.5 \mu \mathrm{g} / \mathrm{ml}$, and

Table 2 Excretion of porphyrins and porphyrin precursors and erythrocyte protoporphyrin concentration in Gilbert's syndrome and variegate porphyria

\begin{tabular}{|c|c|c|c|c|c|c|c|}
\hline & \multirow{2}{*}{$\begin{array}{l}\text { Erythrocyte } \\
\text { protoporphyrin } \\
\text { (nmolll) }\end{array}$} & \multicolumn{4}{|l|}{ Urine } & \multicolumn{2}{|l|}{ Faecal } \\
\hline & & $\begin{array}{l}A L A \\
(\mu \mathrm{mol} / 24 h)\end{array}$ & $\begin{array}{l}P B G \\
(\mu \mathrm{mol} / 24 h)\end{array}$ & $\begin{array}{l}\text { Uroporphyrin } \\
\text { (nmol/24h) }\end{array}$ & $\begin{array}{l}\text { Coproporphyrin } \\
\text { (nmol/24h) }\end{array}$ & $\begin{array}{l}\text { Coproporphyrin } \\
\text { (nmol/gdrywt) }\end{array}$ & $\begin{array}{l}\text { Protoporphyrin } \\
\text { (nmol/gdry wt) }\end{array}$ \\
\hline Normal range & $0-900$ & $0-40$ & $0-16$ & $0-\dot{49}$ & $0-430$ & $0-76$ & $0-200$ \\
\hline $\begin{array}{l}\text { Gilbert's syndrome } \\
\text { mean (range) }\end{array}$ & $\begin{array}{l}620 \\
(474-976)\end{array}$ & $\begin{array}{l}11 \cdot 9 \\
(1-24)\end{array}$ & $\begin{array}{l}4 \\
(0-11)\end{array}$ & $\begin{array}{l}2 \\
(0-4)\end{array}$ & $\begin{array}{l}71 \\
(33-147)\end{array}$ & $\begin{array}{l}30 \\
(22-37)\end{array}$ & $\begin{array}{l}112 \\
(79-139)\end{array}$ \\
\hline $\begin{array}{l}\text { Variegate porphyria } \\
\text { mean (range) }\end{array}$ & $\begin{array}{l}698 \\
(370-1085)\end{array}$ & 45 & $(1-62)$ & $\begin{array}{l}72 \\
(8-141)\end{array}$ & $\begin{array}{l}420 \\
(44-938)\end{array}$ & $\begin{array}{l}558 \\
(66-1400)\end{array}$ & $\begin{array}{l}1243 \\
(355-2536)\end{array}$ \\
\hline
\end{tabular}



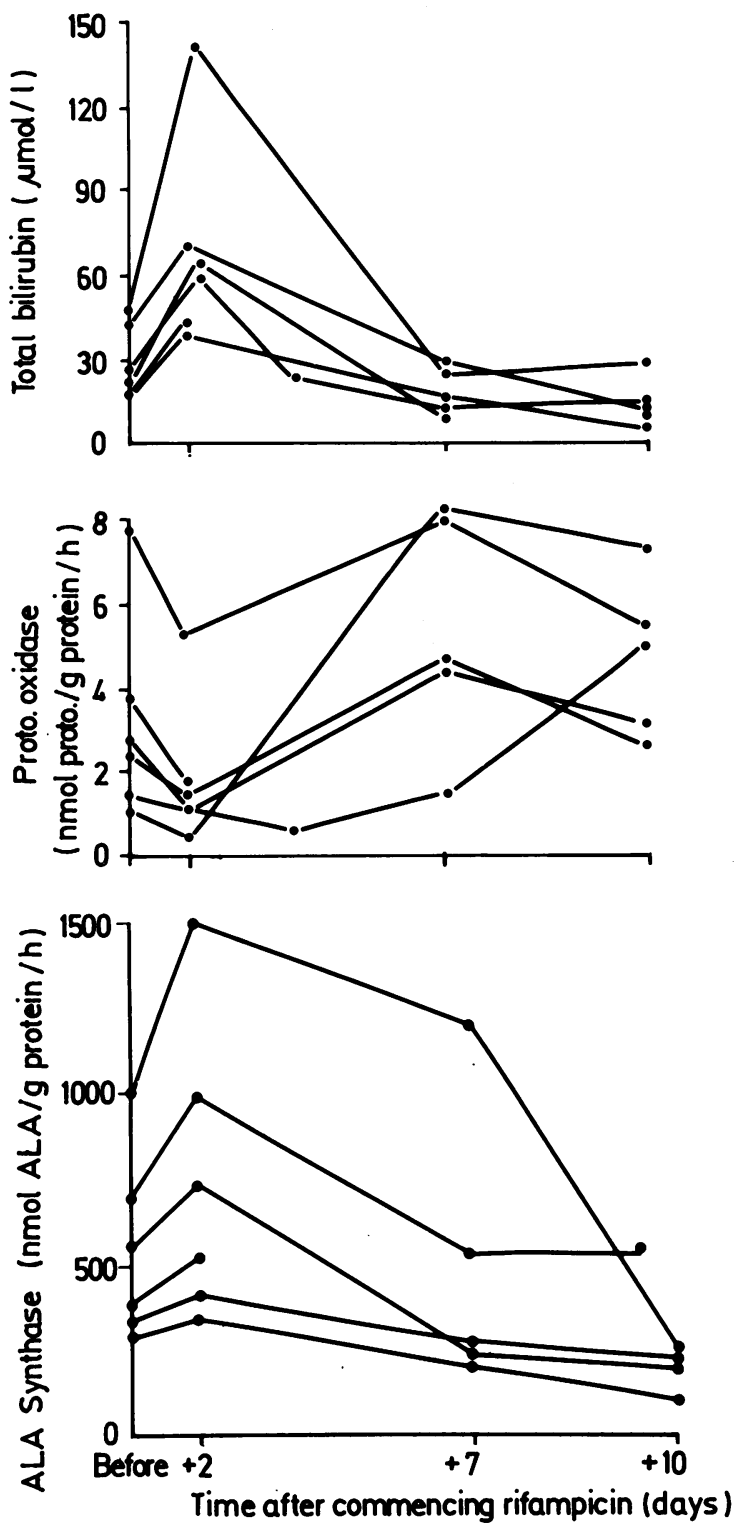

Fig. 3 Effect of rifampicin $600 \mathrm{mg} /$ day on the serum total bilirubin concentration and the activities of PROTO oxidase and $A L A$ synthase in peripheral leucocytes in six subjects with Gilbert's syndrome.

$1 \cdot 15 \pm 1 \cdot 0 \mu \mathrm{g} / \mathrm{ml}$ after the second, seventh and 10th doses respectively. The normalisation of the bilirubin concentration was associated with a rise in PROTO oxidase activity and fall in ALA synthase activity. In the five subjects monitored for 10 days the mean PROTO oxidase activity rose to $4.7 \mathrm{nmol}$ PROTO/g protein/h compared with their pretreatment value of 2.6 and the mean ALA synthase activity fell to 352 nmol ALA/g protein/h compared with their pretreatment value of 580 .

\section{Discussion}

Our observations indicate that in addition to disturbed bilirubin metabolism subjects with Gilbert's syndrome also have abnormalities of haem biosynthesis characterised by increased activity of the initial enzyme of the pathway ALA synthase and reduced activity of the penultimate enzyme PROTO oxidase. Delta-aminolaevulinic acid synthase is the rate controlling enzyme of haem biosynthesis and under negative feedback control by haem. In the acute porphyrias in which there are genetic deficiencies of individual enzymes in the pathway - for example, PROTO oxidase in variegate porphyria, there is a compensatory increase in ALA synthase activity. In Gilbert's syndrome the increased ALA synthase activity can be explained by the reduced PROTO oxidase activity.

The biphasic effect of rifampicin on the unconjugated bilirubin concentration allowed the relationship of the abnormal haem biosynthesis and hyperbilirubinaemia to be examined. The initial rise in the unconjugated bilirubin concentration on starting rifampicin, which is most marked nine hours after each dose, is because of competition for hepatic uptake, and the subsequent normalisation of the bilirubin level, and fall in the serum drug level, because of the induction of this process. ${ }^{1617}$ The reciprocal changes in PROTO oxidase activity suggest that the enzyme is being inhibited by unconjugated bilirubin. The preliminary studies excluded the possibility that the decreased PROTO oxidase activity was artefactual because of bilirubin or rifampicin interfering with the measurement of its activity and the increased ALA synthase activity confirms an in vivo block in haem biosynthesis. The changes in ALA synthase activity with rifampicin therapy are also consistent with unconjugated bilirubin impeding the rate of haem synthesis. The initial increase in ALA synthase activity on rifampicin, however, may also be explained by the haemoprotein inducing effects of the drug. ${ }^{18}$

Bilirubin IX $\alpha$ is structurally very similar to protoporphyrinogen, the normal substrate of PROTO oxidase, and may be acting as a competitive inhibitor. It has been shown in vitro to inhibit the enzyme ferrochelatase which has protoporphyrin as its substrate. ${ }^{19}$ Unfortunately, no purified preparations of PROTO oxidase are currently available for satisfactory in vitro inhibitory studies. If hyperbilirubinaemia is responsible for the decreased PROTO oxidase activity in Gilbert's syndrome, a significant negative correlation of the two might have been 
expected. Two reasons may account for the absence of this. Firstly, it is likely to be the unconjugated and unbound fraction of bilirubin which will inhibit the enzyme and currently there is no satisfactory assay for accurately measuring this, and secondly there may not be a direct linear correlation between the concentration of bilirubin in the serum and its concentration in the vicinity of the enzyme PROTO oxidase which is sited on the inner mitochondrial membrane.

If subjects with Gilbert's syndrome have an enzymatic defect similar to variegate porphyria they might be expected to have increased porphyrin excretion. This does not invariably follow, however, as a proportion of patients with variegate porphyria have normal porphyrin excretion when asymptomatic. ${ }^{20}$ The tissue in which the enzyme abnormalities are present is also important. In the porphyrias, the enzyme defect is thought to be present in all cells though the porphyrin overproduction is mainly hepatic in origin. ${ }^{21}$ In Gilbert's syndrome the enzyme defect has been shown in peripheral leucocytes and we have no information regarding haem biosynthesis in the liver. If the impaired haem biosynthesis in Gilbert's syndrome is the result of the unconjugated hyperbilirubinaemia and Gilbert's syndrome is because of impaired hepatic uptake of unconjugated bilirubin, then intrahepatic haem biosynthesis would be spared and there would be no increased porphyrin excretion because of hepatic overproduction.

Abnormalities of porphyrin excretion do occur in the Dubin-Johnson syndrome and Rotor's syndrome in which the hereditary defects in hepatic bilirubin handling involve hepatocellular excretion rather than uptake or conjugation of the pigment,,$^{223}$ and also in obstructive jaundice. ${ }^{24}$ In 1981 , Evans et al ${ }^{25}$ reported a patient with conjugated hyperbilirubinaemia resembling that seen in Rotor's syndrome, who also had unexplained increased faecal porphyrin excretion typical of variegate porphyria. Though some of these porphyrin abnormalities associated with conjugated hyperbilirubinaemia can be explained by impaired hepatic porphyrin excretion, abnormal hepatic porphyrin synthesis caused by increased hepatocellular bilirubin concentrations may also be important.

This work was supported by a biomedical research grant from the Scottish Home and Health Department.

\section{References}

1 Gilbert A, Lereboullet P. La Cholemie simple familale. Sem Med 1901; 21: 241-5.
2 Berk PD, Bloomer JR, Howe RB, Berlin NI. Constitutional hepatic dysfunction (Gilbert's syndrome): a new definition based on kinetic studies with unconjugated radio-bilirubin. Am J Med 1970; 49: 296-305.

3 Powell LW, Hemingway E, Billing BH, Sherlock S. Idiopathic unconjugated hyperbilirubinaemia (Gilbert's syndrome): a study of 42 families. $N$ Engl J Med 1967; 277: 1108-12.

4 Frezza M, Perona G, Corrocher R, Cellerino R, Bassetto MA, Desandre G. Bilirubin - $\mathrm{H}^{3}$ kinetic studies: pattern of normals, Gilbert's syndrome and hemolytic state. Acta Hepato-Gastroenterol 1973; 20: 363-71.

5 Goresky CA, Gordon ER, Shaffer EA, Pare P, Carrasavas D, Aronoff A. Definition of a conjugation dysfunction in Gilbert's syndrome: studies of the handling of bilirubin loads and of the pattern of bilirubin conjugates secreted in bile. Clin Sci Mol Med 1978; 55: 63-71.

6 Black M, Billing BH. Hepatic bilirubin- UDPglucuronyl transferase activity in liver disease and Gilbert's syndrome. N Engl J Med 1969; 280: 1266-71.

7 Felsher BF, Craig JR, Carpio N. Hepatic bilirubin glucuronidation in Gilbert's syndrome. J Lab Clin Med 1973; 81: 829-37.

8 Blanckaert N, Schmid R. Physiology and pathophysiology of bilirubin metabolism. In: Zamin D, Boyer TD, eds. Hepatology. Philadelphia: WB Saunders, 1982: 246-96.

9 Berk PD. Pathophysiology, diagnosis and treatment of the hereditary hyperbilirubinaemias. In: Williams R, Maddrey WC, eds. Gastroenterology 4. London: Butterworths, 1984: 1-51.

10 Moore MR, Thompson GG, Goldberg A, Ippen $\mathbf{H}$, Seubert A, Seubert $S$. The biosynthesis of haem in congenital (erythropoietic) porphyria. Int $J$ Biochem 1978; 9: 933-8.

11 Brenner DA, Bloomer JR. A fluorimetric assay for measurement of protoporphyrinogen oxidase activity in mammalian tissue. Clin Chim Acta 1980; 100: 259-66.

12 Michaelsson M, Nosslin B, Sjolin S. Plasma bilirubin determinations in the newborn infant. Pediatrics 1965; 35: $925-31$.

13 Seubert A, Seubert S. High performance liquid chromatographic analysis of porphyrins and their isomers with radial compression columns. Anal Biochem 1982; 124: 303-7.

14 Moore MR. Laboratory Investigation of disturbances of porphyrin metabolism. Association of Clinical Pathologists. Broadsheet 109. London: BMA, 1983.

15 McConnell JB, Smith H, Davis M, Williams R. Plasma rifampicin assay by an improved solvent extraction technique. Br J Clin Pharmacol 1979; 8: 506-7.

16 Acocella G. Clinical pharmacokinetics of rifampicin. Clin Pharmacokinet 1978; 3: 108-27.

17 Frezza M, Pozzato G, Quaronto C, Tiribelli C, Piccinini C. Abnormality in the hepatic transport of rifamycin SV in Gilbert's syndrome. Ital J Gastroenterol 1980; 12: $1-5$.

$18 \mathrm{McColl} \mathrm{KEL,} \mathrm{El} \mathrm{Omar} \mathrm{E,} \mathrm{Macphee} \mathrm{GG,} \mathrm{et} \mathrm{al.} \mathrm{Effects} \mathrm{of}$ rifampicin on haem biosynthesis and hepatic mono- 
xygenase activity in healthy subjects. $\mathrm{Br} J$ Clin Pharmacol. (In press.)

19 Labbe RF, Zaske MR, Aldrich RA. Bilirubin inhibition of heme biosynthesis. Science 1959; 129: 1741-2.

20 Mustajoki P. Variegate porphyria. $Q J$ Med 1980; 44: 191-203.

21 Marver HS, Schmid R. In: Stanbury, Wyngaarden, Frederickson, eds. The metabolic basis of inherited disease. New York: McGraw-Hill, 1972: 851-5.

22 Kondo, T, Kuchiba K, Shimizu Y. Coproporphyrin isomers in Dubin-Johnson syndrome. Gastroenterology 1976; 70: 1117-20.

23 Shimizu Y, Naruto H, Ida S, Konakura M. Urinary coproporphyrin isomers in Rotor's syndrome. A study in eight families. Hepatology 1981; 1: 173-8.

24 Rover CM. Urinary porphyrin pattern in liver damage. Fd Chem Toxic 1984; 22: 241-3.

25 Evans J, Lefkowitch J, Lim CK, Billing B. Faecal porphyrin abnormalities in a patient with features of Rotor's Syndrome. Gastroenterology 1981; 81: 1125-30. 